\title{
Chypre de l'ère ottomane à l'ère britannique (1839-1914). Le rôle de l'Église orthodoxe chypriote
}

\section{Athanassia Anagnostopoulou}

\section{OpenEdition}

Journals

Édition électronique

URL : http://journals.openedition.org/etudesbalkaniques/217

ISSN : 2102-5525

\section{Éditeur}

Association Pierre Belon

\section{Édition imprimée}

Date de publication : 1 janvier 1998

ISBN : 2-910860-08-6

ISSN : $1260-2116$

Référence électronique

Athanassia Anagnostopoulou, «Chypre de l'ère ottomane à l'ère britannique (1839-1914). Le rôle de l'Église orthodoxe chypriote », Études balkaniques [En ligne], 5| 1998, mis en ligne le 03 décembre 2008, consulté le 01 mai 2019. URL : http://journals.openedition.org/etudesbalkaniques/217

Ce document a été généré automatiquement le 1 mai 2019.

Tous droits réservés 


\title{
Chypre de l'ère ottomane à l'ère britannique (1839-1914). Le rôle de l'Église orthodoxe chypriote
}

\author{
Athanassia Anagnostopoulou
}

\section{RÉSUMÉS}

Par sa position au sein du système politique ottoman, l'Église autocéphale de Chypre a représenté l'autorité morale et politique de la communauté grecque durant tout le XIX siècle, renforçant ce rôle durant la période des Réformes. L'arrivée des Britanniques, en 1878, entraîne cependant des transformations institutionnelles au terme desquelles l'Église perd ses fonctions antérieures; elle est alors tenue de légitimer sa place en adoptant une ligne politique nationaliste qui l'oblige à s'allier aux laïcs porteurs d'une politique irrédentiste.

\section{AUTEUR}

\section{ATHANASSIA ANAGNOSTOPOULOU}

Université de Chypre 